\section{Shaking the very foundations}

\section{Warwick Bray}

Debating Archaeology. By Lewis R. Binford. Academic: 1989. Pp. 534. \$44.95, $£ 28.50$.

EVERY few years Lewis Binford reissues a collection of his essays, a form of intellectual autobiography that invites the reviewer to assess the author's personality and significance within the profession, as well as his views on particular archaeological subjects. In the case of Binford, who has done little to discourage the cult of personality, it is almost impossible to separate the man from his works. To his many admirers he is the greatest archaeological thinker of his generation and a true prophet; others regard him as archaeology's equivalent of a television evangelist. On the evidence of the present book, both these views are exaggerated.

The papers included here have been published in various journals between 1983 and 1989. The first group deals with Binford's familiar themes - what archaeology is for, and how it should be carried out. In his usual trenchant style he sets about his old enemies, the postprocessualists and the empiricists, and, eventually, attacks just about every new idea since the 1970 s which he did not think up himself.

These chapters are full of robust common sense and, as an exercise in debunking theoretical pretension, are a delight to read. But, one is entitled to ask, is Binford's own philosophy of archaeology any more convincing than those he attacks? Since the 1960 s he has asked important but awkward questions, and has done more than anyone to improve data handling by insisting that things are made objective, quantifiable and testable, as far as these ideals can ever be realized in archaeology. In the end, though, Binford (like most of his opponents) is preaching a personal faith. When he says (p. 115) that "the practical limitations of our knowledge of the past are not inherent in the nature of the archaeological record" but are due to "our methodological naivete", this is simply a statement of faith, a personal opinion masquerading as an axiom, and I, for one, do not believe it. By all means let us improve out methodology, but I doubt that this will somehow make all things knowable.

Similarly, Binford's insistence that archaeology is a science, repeated again and again throughout the book, may give the subject a spurious respectability, but is untrue. Science does not have a monopoly on logic, and the fact that archaeologists draw on scientific evidence (as a judge might listen to a forensic specialist) does not in itself make archaeology a science. This kind of statement ignores the whole purpose of the investigation, and reduces archaeology to a largely descriptive discipline, one which has no way of tackling problems of causality (the traditional preserve of philosophers, historians and theologians) and, indeed, one which has no legitimate interest in such things.

This attitude explains the preoccupation of the "new archaeology in the 1960s with the search for laws of human behaviour, analogous to 'scientific' laws governing, say, the behaviour of gasses. Strangely, the failure to find such laws has done little to destroy the myth of archaeology as science. At a deeper level of analysis, as neither philosophers nor scientists can agree about why human cultures have developed as they have, there is no reason to expect a consensus among archaeologists. Nevertheless, at times the debate seems more like a power-struggle between competing prophets than a genuine search for truth. What I object to most of all is the way in which each theoretician insists that his is the only way to do archaeology. This is nonsense, and is intellectual totalitarianism of the worst kind.

Although the early chapters of this book will provoke and stimulate anyone with an archaeological conscience, the later ones concern more specialized matters: ethnoarchaeological studies of stone-quarrying and tool-manufacture by Australian aborigenes; butchering practices among the Nunamiut Eskimos; and the taphonomy of Pleistocene bone assemblages and their significance for reconstructing early human behaviour. Binford here applies his own methodological principles to real archaeological problems, with an awareness that almost any case study can be the starting point for a discussion of wider issues.

A quick check among my colleagues suggests that Binford's conclusions are not widely accepted by Pleistocene specialists, but in a book called Debating Archaeology the questions matter more than the answers. In future histories of archaeology, Binford may not figure in the list of those who solved the great archaeological problems, but he certainly deserves a place as a teacher and polemicist, a person who has forced us all to think.

Warwick Bray is at the Institute of Archaeology, 31 Gordon Square, London WC1H OPY, UK.

\section{New in paperback}

- Theology and the Scientific Imagination: from the middle ages to the seventeenth century by $\mathrm{A}$. Funkenstein, published in 1986, is now available in paperback. The author attempts to define the points of transition from mediaeval to early modern modes of reasoning. Published by Princeton University Press, price $\$ 14.50$.

\section{Emerging from the deep}

\section{P.J. Butler}

Diverse Divers: Physiology and Behavior. By G. L. Kooyman. Springer-Verlag: 1989 Pp. 200. DM 178, £63.50, \$99.

THOSE reptiles, birds and mammals that spend much of their time submerged under water are often in the public eye. Conservation of whales and marine turtles, viral infections of seals and the effect of oil spillages on all marine life - especially, perhaps, birds - has put these animals firmly in the news. Largely from the observation of the early whalers, the ability of some of these air-breathing vertebrates to remain under water for impressively long durations has been studied for more than a century. Only relatively recently has it been possible for the behaviour and physiology of these fascinating animals to be investigated together. One of the pioneers of such studies and an undoubted world expert on the subject is the author of Diverse Divers. Nevertheless, because of the detailed nature of the book, I doubt that it will be read by many laymen.

The book's theme is how the anatomy and physiology of animals sets the limits of their behaviour and thus of their exploitation of the sea. As such, I found it frustrating that the animals' behaviour is dealt with at the end - this is certainly a case where I strongly recommend that the reader begins with the last chapter to put the rest of the book into its rightful context.

The main problem facing diving vertebrates is the management of the body's oxygen stores during the period of submersion. Kooyman covers all the factors affecting the size of these stores and the rate at which they are used. The clear conclusion is that, contrary to the traditional view, the vast majority of underwater activity, be it feeding, exploration or merely moving from one place to another, is fuelled by aerobic metabolism. Although perfectly logical, this is nonetheless remarkable in an animal such as the female northern elephant seal which, after weaning her pup, spends almost 90 per cent of her time under water at depths usually in excess of 200 metres. Kooyman emphasizes the very pertinent point made by Kramer in 1988, that animals such as these should be called surfacers and not divers.

Kooyman's first-hand experience of working in the field with the subjects of the book is apparent from the enthusiastic way in which he writes. Unfortunately, many of his stated objectives are not always achieved, and there are several 